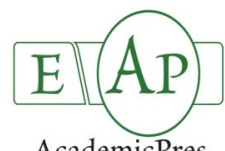

\title{
Effect of Light Intensity and Temperature on Growth and Quality Parameters of Grafted Vines
}

\author{
Bülent KÖSE \\ Ondokuz Mayis University, Faculty of Agriculture, Department of Horticulture, 55139 Atakum, Samsun, Turkey; bulentk@omu.edu.tr
}

\begin{abstract}
Light and temperature are the most important environmental conditions that impact the growth and quality of grafted vines. In this research, the most suitable light and temperature conditions were tested to determine the best environment for grafted vines grown in pots. This study was conducted to determine the influence of different growth conditions, such as open field, shaded greenhouse and unshaded greenhouse, on grafted vine growth and quality. The length and diameter of shoot, trunk diameter, mean and total leaf area, total soluble sugars, starch and total carbohydrate contents of 'Narince' and 'Trakya Ilkeren' vines, grafted on $5 \mathrm{C}$ rootstock, were investigated in this study. Shaded conditions yielded significantly higher shoot lengths, mean and total leaf areas than other conditions $(p<0.05)$. Among the growth parameters, the highest correlation $(\mathrm{r}=$ $0.819)$ was observed between shoot length and plant total leaf area $(p<0.01)$. The total soluble sugars, starch and total carbohydrates content of vines under shaded and unshaded conditions were higher $(p<0.05)$ than those under open field conditions. Grafted vines had the highest carbohydrate content in unshaded conditions. Under different light intensity, temperature and relative humidity conditions studied, the better results were obtained in the case of unshaded conditions.
\end{abstract}

Keywords: carbohydrates, grapevine, light, quality, temperature

\section{Introduction}

Grafting Vitis vinifera varieties onto resistant rootstocks represents the most effective way of protecting crops against phylloxera (Vršič et al., 2004). Especially in phylloxeracontaminated areas, where the establishment of suitable vines on their own roots is virtually impossible. The only successful means of controlling phylloxera has been the grafting of phylloxera resistant rootstock (Troncoso et al., 1999). Because of this, grafted vines should be be used during the establishment of new vineyards regardless of the phylloxera infection. Quality grafted vines allow for the successful growth and development of both root and vegetative organs after planted in a vineyard. Healthy vineyards are only possible with healthy and quality grafted vines. Nursery soil characteristics and climate conditions have significant impacts on the success of grafted vine operations especially during the initial 2-3 weeks after planting grafted cuttings (Çelik et al., 1992). For successful production, control of the nursery's climatic conditions should be taken. A temperature of $25^{\circ} \mathrm{C}$ and $85-95 \%$ relative humidity should be provided within the growing conditions for good callus formation (Karakır et al., 1988). Several other environmental factors also affect the growth and development of the plants (Arnold and Mauseth; 1999; Buttrose, 1969; Bindi et al., 1997; Oztürk and Serdar, 2011). The most important of these factors are light, temperature, water (humidity) and nutrition. Light and temperature are two important parameters that affect the physiology of the grapevine. Plants are need light and temperature for basic physiological processes such as photosynthesis, respiration transpiration and carbohydrate assimilation (Agaoglu et al., 1995; Uzun and Demir, 1996). Sivritepe and Türkben (2001) was obtained rooting grafted cuttings between $30.47 \%$ and $73.75 \%$ on five different rootstocks belonging to the 'Müşküle' grape variety at $25 \pm 2^{\circ} \mathrm{C}$ temperature, $70-75 \%$ humidity and 16 hours photoperiod. Yllma (1996) stated that 5BB grafting cuttings of 'Abalıkoca' and 'Kazova' grapes grown under white transparent polythene plastic mini tunnel systems gave the highest rooting rate. Light is another crucial environmental factor determining the morphology and physiology of leaves (Neri et al., 2003). It plays a significant role in physiological processes in plants such as photosynthesis and transpiration (Fluhr et al., 1986; Wang et al., 2014). Sultanina grapes growing under greenhouse conditions required light intensity and temperature at respective rates of 60.000 lux and $25^{\circ} \mathrm{C}$ for optimum assimilation rates (Kriedemann, 1968). Kismalı (1984) reported certain increases in photosynthesis capacities with increasing light intensities of greenhouses but also noted that photosynthesis reached full capacity at a certain point even with increasing light intensities.

Carbohydrates, which are stored in plants' roots, trunks, cordons and canes, play major roles in the growth and 
development of plants. During the bud burst period, carbohydrates are moved from the roots and woody organs to the growing shoot, providing new leaves and other organs with essential reserves needed for growth. Young shoots and leaves utilize carbohydrates for growth and metabolism until they reach approximately a third of their final size (Hale and Weaver, 1962). Buttrose (1968) stated that dry weights of roots, canes, stems, and leaves increased with increasing light intensity and were greater at $25^{\circ} \mathrm{C}$ than at $20^{\circ} \mathrm{C}$ or $30^{\circ} \mathrm{C}$. Richards (1976) reported that grafted vines produced very good growth results in an environment of around $25{ }^{\circ} \mathrm{C}$. Researchers suggested the optimum temperature for the photosynthesis of grapevines as between $25^{\circ} \mathrm{C}$ and $35^{\circ} \mathrm{C}$ (Greer and Weedon, 2012; Kriedemann, 1968; Mullins et al., 1992; Schultz, 2000). However, temperatures above $35{ }^{\circ} \mathrm{C}$, generally reduced the photosynthesis rates of grape leaves (Ferrini et al., 1995; Kriedemann, 1968; Luo et al., 2011; Yu et al., 2009; Zsófi et al., 2009). The lowest net photosynthesis values were recorded in vines grown at $35{ }^{\circ} \mathrm{C}$ and were closely correlated to chlorophyll content. The effect of this temperature on stomatal conductance was less remarkable and the dry matter accumulation was correlated to average photosynthesis rates (Ferrini et al., 1995).

From dig out till grafting, various factors effect vine growth and quality. The quality of grafted vines diminishes after planting vineyards. Having the best quality vines is a crucial factor for successful grapevine growing. The aim of this study was to determine the influence of different growth conditions (open field, shaded greenhouse and unshaded greenhouse) on the growth and carbohydrate content of grafted vines.

\section{Materials and methods}

Experiments were conducted in the experimental fields and plastic greenhouses of Ondokuz Mayis University's Agricultural Faculty. 'Narince' and 'Trakya Ilkeren' scions (Vitis vinifera L. cvs.) were grafted on $5 \mathrm{C}$ rootstock. 'Narince' is the most important white wine grape in Turkey and is used both as a table food and for wine in the country. 'Trakya Ilkeren' ('Alphonse Lavallée' x 'Perlette') is a very early maturing red table grape. In addition, this grape is quite suitable as a wrapping leaf for foods and for greenhouse cultivation. Material supply, grafting and callusing processes were performed at Tekirdag Viticultural Research Station. The scions and rootstocks were stored at $+2{ }^{\circ} \mathrm{C}$ until two months until grafting. The omega grafting was done at the beginning of April and grafted cuttings were stored for 3 weeks at $28^{\circ} \mathrm{C}$ and one week at $26^{\circ} \mathrm{C}$ in a callusing room. Callused cuttings were planted in 10-L plastic pots with a soil, sand and manure (1:1:1) potting mix (substrate content not analyzed). Plants were irrigated everyday with $1.5 \mathrm{~L}$ of water in the early morning. In order to provide different light and temperature conditions, vines were grown in shaded and unshaded greenhouse and open field conditions. Similarly, to render equal soil conditions, the vines were grown in pots. The pots were placed under different growth conditions at the beginning of May. Among the rooted ones, uniformly growing vines were selected for the calculation of certain growth parameters. Shading was provided through netting with a light transmission of $50 \%$. The temperature and relative humidity were measured with a data logger and resultant values are provided in Figs. 1 and 2 for both experimental years. Light intensity (PAR) was measured in 15-day periods between the months of June and September of both years with a canopy analyzer device and expressed in $\mu m o l m^{-2} s^{-1}$ (Tab. 1 and Fig. 3). In the study, some growth parameters such as total and mean leaf area, shoot length, trunk and shoot diameter were measured in August. Mean leaf area was determined by dividing the total leaf area of the shoot with the number of leaves over the main shoot. Leaf areas were calculated nondestructively $\left[-1.41+0.527\left(\mathrm{~W}^{2}\right)+0.254\left(\mathrm{~L}^{2}\right)\right]$ according to Elsner and Jubb (1988). All measurements were repeated in the second year on annual cuttings.

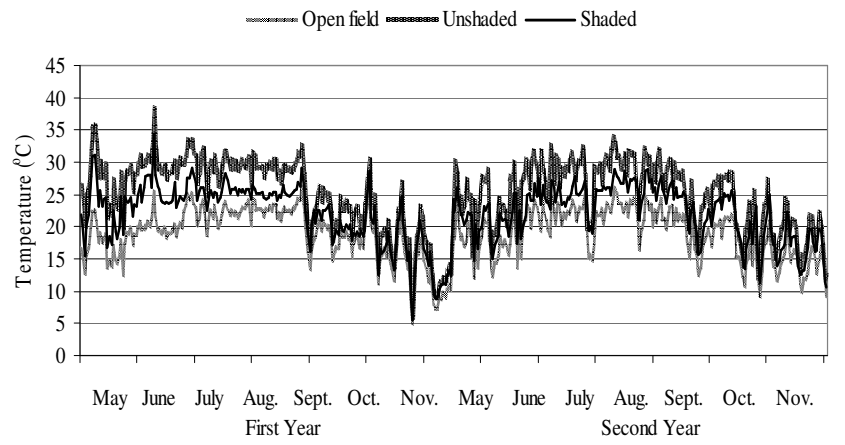

Fig. 1. Course of temperature throughout the experimental years

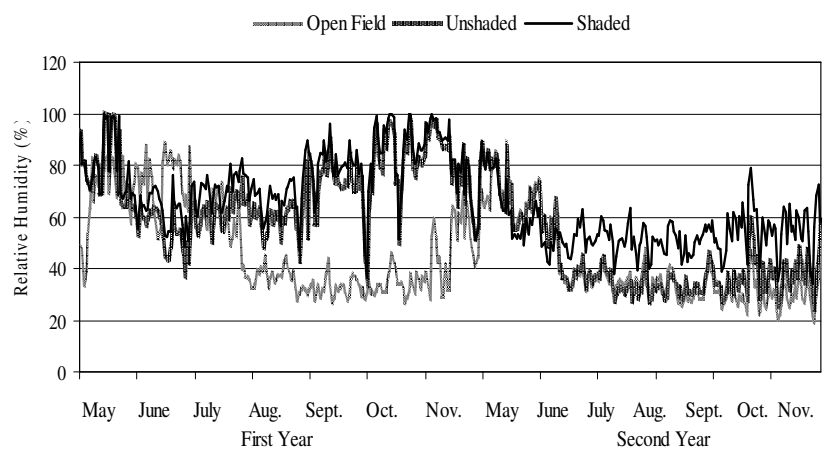

Fig. 2. Course of relative humidity throughout the experimental years

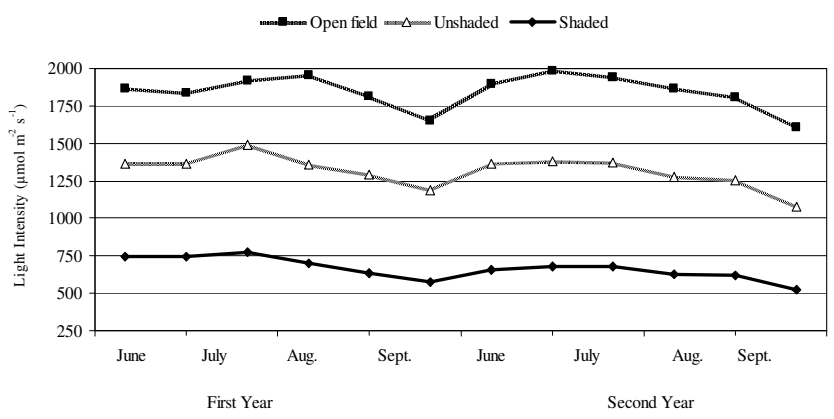

Fig. 3. Course of light intensity throughout the experimental years

\section{Carbohydrate analysis}

During the dormant periods of the plants, a $2 \mathrm{~cm}$ piece between the $2^{\text {nd }}$ and $3^{\text {rd }}$ nodes from the bottom of the canes; a $2 \mathrm{~cm}$ piece from the mid-section of the stem; a piece between 2.5-4 mm from the older sections of the roots; and a $1-2 \mathrm{~mm}$ piece from the younger sections of the roots were cut out and grinded together (Bates et al., 2002). Plant 
509

tissue samples were pulverized in a mill with a 40-mesh screen for analysis and $200 \mathrm{mg}$ of dust was used for the extraction. Soluble sugars were extracted twice with $8 \mathrm{ml}$ of $80 \%$ ethanol at $60^{\circ} \mathrm{C}$ for 30 minutes (Candolfi and Koblet, 1990). The content of soluble sugars was determined with the anthrone method as described by Scott and Melvin (1953). Starch was extracted twice with $8 \mathrm{ml}$ of $1 \mathrm{M}$ perchloric acid, one hour each time at $60^{\circ} \mathrm{C}$ and measured by the same method. Absorbance readings were made at $620 \mathrm{~nm}$ with a spectrophotometer. Glucose was used as a standard for the analysis of soluble sugars and starch.

\section{Experimental design}

The randomized complete block design, with three replications, was used both years. Every replication consisted of four uniformly grown grafted vines. Growing conditions, cultivars, years and these interactions were studied by threefactored ANOVA. Data analysis was performed using SPSS 16.0 for Windows. Results studied are presented as means and a pooled standard error of mean (SEM). Differences among means were detected using Duncan's multiple range tests, which were used for statistical analyses $(p \leq 0.05)$. Correlation analysis was applied to assess the relationship between growth parameters and sugar, starch and total carbohydrates.

\section{Results and discussion}

\section{Changes in temperature, humidity and light intensity}

Data related to average temperature $\left({ }^{\circ} \mathrm{C}\right)$, relative humidity (\%) and light intensity $\left(\mu \mathrm{molm}^{-2} \mathrm{~s}^{-1}\right)$ determined daily after the planting of grafted cuttings during the research are shown in Tab. 1 and Fig. 1, 2 and 3. Average temperature, relative humidity and light intensity values under different growth conditions throughout the growth seasons of experimental years are provided in Tab. 1 .

Under unshaded, shaded and open field conditions, average temperatures were respectively calculated as 24.9 ${ }^{\circ} \mathrm{C}, 22.1{ }^{\circ} \mathrm{C}$ and $18.8^{\circ} \mathrm{C}$. Under the same conditions, average light intensities were respectively calculated as $1315.4,662.2$ and $1846.1 \mu \mathrm{mol} \mathrm{m}^{-2} \mathrm{~s}^{-1}$.

\section{Vine growth and development}

Shoot lengths and diameters, trunk diameters, total and mean leaf areas of grape cultivars grafted on $5 \mathrm{C}$ rootstocks under different conditions (shaded and unshaded greenhouses and open field) for both years are presented in Tab. 2. Shoot lengths were significantly affected by growth conditions, year and growth conditions $\mathrm{x}$ year interaction $(p<0.05)$. The shoot lengths were higher under shaded

Tab. 1. Temperature, relative humidity and light intensity values under different nursery conditions throughout the growth seasons of experimental years

\begin{tabular}{|c|c|c|c|c|}
\hline \multirow{2}{*}{ Years } & \multirow{2}{*}{ Parameters } & \multicolumn{3}{|c|}{ Conditions } \\
\hline & & Unshaded & Shaded & Open Field \\
\hline \multirow{3}{*}{ First Year } & Light Intensity $\left(\mu \mathrm{mol} \mathrm{m}^{-2} \mathrm{~s}^{-1}\right)$ & 1343.1 & 695.0 & 1841.1 \\
\hline & Temperature $\left({ }^{\circ} \mathrm{C}\right)$ & 25.1 & 22.0 & 18.7 \\
\hline & Relative Humidity (\%) & 69.8 & 75.9 & 49.4 \\
\hline \multirow{3}{*}{ Second Year } & Light Intensity $\left(\mu \mathrm{mol} \mathrm{m}^{-2} \mathrm{~s}^{-1}\right)$ & 1287.7 & 629.3 & 1851.1 \\
\hline & Temperature $\left({ }^{\circ} \mathrm{C}\right)$ & 24.7 & 22.1 & 18.9 \\
\hline & Relative Humidity (\%) & 44.9 & 56.2 & 41.3 \\
\hline
\end{tabular}

Tab. 2. Shoot lengths $(\mathrm{cm})$ and diameters $(\mathrm{mm})$, trunk diameters $(\mathrm{mm})$, total and mean leaf areas $\left(\mathrm{cm}^{2}\right)$ of different grafted vine cultivars under different conditions

\begin{tabular}{|c|c|c|c|c|c|c|}
\hline \multirow{2}{*}{ Growth conditions } & \multirow{2}{*}{ Cultivars } & \multirow{2}{*}{$\begin{array}{c}\text { Trunk } \\
\text { Diameter }\end{array}$} & \multicolumn{2}{|c|}{ Shoot } & \multicolumn{2}{|c|}{ Leaf Area } \\
\hline & & & Length & Diameter & Total & Mean \\
\hline \multicolumn{7}{|c|}{ First Year } \\
\hline \multirow{2}{*}{ Open field } & 'Narince' & 14.3 & 75.0 & 9.9 & 3420.0 & 65.2 \\
\hline & 'T.Ilkeren' & 13.6 & 92.3 & 8.9 & 3786.0 & 42.6 \\
\hline \multirow{2}{*}{ Unshaded } & 'Narince' & 15.0 & 118.0 & 9.3 & 3840.0 & 74.6 \\
\hline & 'T.Ilkeren' & 13.7 & 114.8 & 9.4 & 5729.0 & 57.5 \\
\hline \multirow{2}{*}{ Shaded } & 'Narince' & 14.4 & 268.5 & 10.0 & 6435.0 & 116.9 \\
\hline & 'T.Ilkeren' & 15.0 & 250.0 & 10.3 & 8164.0 & 88.7 \\
\hline \multicolumn{7}{|c|}{ Second Year } \\
\hline \multirow{2}{*}{ Open field } & 'Narince' & 11.8 & 46.5 & 6.5 & 1865.0 & 55.7 \\
\hline & 'T.Ilkeren' & 12.3 & 47.3 & 6.3 & 1843.0 & 39.0 \\
\hline \multirow{2}{*}{ Unshaded } & 'Narince' & 10.9 & 118.5 & 6.9 & 2439.0 & 63.0 \\
\hline & ‘T.Ilkeren’ & 12.1 & 117.5 & 6.8 & 3794.0 & 54.4 \\
\hline \multirow{2}{*}{ Shaded } & 'Narince' & 12.3 & 133.0 & 6.8 & 3130.0 & 97.6 \\
\hline & 'T.Ilkeren' & 12.6 & 155.0 & 6.4 & 4145.0 & 69.8 \\
\hline Pooled SEM ${ }^{*}$ & & 0.134 & 4.615 & 0.117 & 90.234 & 1.357 \\
\hline Conditions & & N.S & $*$ & N.S & * & $*$ \\
\hline Cultivars & & N.S & N.S & N.S & * & * \\
\hline Year & & $*$ & * & * & * & $*$ \\
\hline Conditions x Cultivars & & N.S & N.S & N.S & * & N.S \\
\hline Conditions x Year & & N.S & $*$ & N.S & * & N.S \\
\hline Cultivars x Year & & ${ }^{*}$ & N.S & N.S & N.S & N.S \\
\hline Conditions $\mathrm{x}$ Cultivars $\mathrm{x}$ Year & & N.S & N.S & N.S & * & N.S \\
\hline
\end{tabular}


conditions than in other growth conditions. In the study, decreasing light intensities and increasing temperatures conditions affected shoot lengths. Low light intensities and high temperatures (shaded and unshaded) lead to the elongation of plant heights (Fig. 4). Mean shoot length was $201.6 \mathrm{~cm}$ under shaded greenhouse conditions, $117.2 \mathrm{~cm}$ under unshaded greenhouse conditions and $62.3 \mathrm{~cm}$ under open field conditions (Tab. 3).

Year also significantly affected growth characteristics (Tab. 2). Strong shoot and leaf development of the first year also resulted in larger shoot diameter the same year. Similarly, trunk diameter of vines in the first year was also larger than in the second year. This was due to weak growth in the second year. Although similar environmental conditions and cultural practices were applied, all growth parameters in the first year were higher than in the second year. These differences might have been from a difference in the organic composition of the soil mix and relative humidity. There was no effect of cultivars on growth. The cultivars were only significant on leaf areas. Larger leaf areas of growing vines were obtained under shaded conditions. Despite the fact that shoot and trunk diameters were not affected by growing conditions (Tab. 2, 3), there was a trend for the shoot and trunk diameters under the shaded greenhouse conditions in both years to be higher $(8.4 \mathrm{~mm}$ and $13.6 \mathrm{~mm}$, respectively) (Tab. 3).

Tab. 3. Mean shoot length $(\mathrm{cm})$ and diameter $(\mathrm{mm})$, trunk diameter $(\mathrm{mm})$ and leaf area $\left(\mathrm{cm}^{2}\right)$ values of grafted vines under different conditions

\begin{tabular}{|c|c|c|c|c|c|}
\hline \multirow{2}{*}{$\begin{array}{l}\text { Growth } \\
\text { conditions }\end{array}$} & \multirow{2}{*}{$\begin{array}{c}\text { Trunk } \\
\text { Diameter }\end{array}$} & \multicolumn{2}{|c|}{ Shoot } & \multicolumn{2}{|c|}{ Leaf Area } \\
\hline & & Length & Diameter & Total & Average \\
\hline Open field & 13.0 & $62.3 \mathrm{c}$ & 7.9 & $2728 \mathrm{c}$ & $50.6 c$ \\
\hline Unshaded & 12.9 & $117.2 \mathrm{~b}$ & 8.1 & $3950 \mathrm{~b}$ & $62.4 \mathrm{~b}$ \\
\hline Shaded & 13.6 & $201.6 a$ & 8.4 & $5468 a$ & $93.2 \mathrm{a}$ \\
\hline
\end{tabular}

Shoots lengths, mean and total leaf areas per plant were affected by the growth conditions (Tab. 2). Light intensity measured under shaded conditions was about one-third of that in open field conditions (Tab. 1). Shoot length increased with decreasing light intensity. Leaves growing at different light levels differ in their anatomy and physiology. While increasing light intensities yield improved photosynthesis rates of vine leaves, decreasing light intensities cause longer internode spacing, weak growth, embrittelement and larger leaf areas. Aside from this, such decreasing lighting intensities also result in decreased photosynthesis rates, etiolating and defoliation (Eris, 1990). The results of the study indicated that different light and temperature conditions had significant effects on shoot growth, total leaf area and mean leaf area, especially in the shaded conditions. According to TS 3981 (Anonymous, 1995), first class vines have to have at least $20 \mathrm{~cm}$ of shoot length and a trunk diameter of $7 \mathrm{~mm}$. In the study, the average shoot length was above $60 \mathrm{~cm}$, shoot diameter was $7.9 \mathrm{~mm}$ and trunk diameter was $12.9 \mathrm{~mm}$. All growth combinations of the first class of grafted vines were according to growth parameters studied in the research (Fig. 4).

Temperature is the most important environmental factor for canopy development and leaf photosynthesis
(Baldocchi and Amthor, 2001; Koblet, 1984; Matloobi, 2012). Field et al. (2009) reported that the shoot and trunk dry biomass of potted Shiraz grapevines grown at $23{ }^{\circ} \mathrm{C}$ in a glasshouse were significantly greater than those grown at 13 ${ }^{\circ} \mathrm{C}$. Skelton (2007) reported that the soil surface requires a cover of black polythene to keep in moisture and raise the soil temperature to aid in vine development, a strong graft union and good root system.

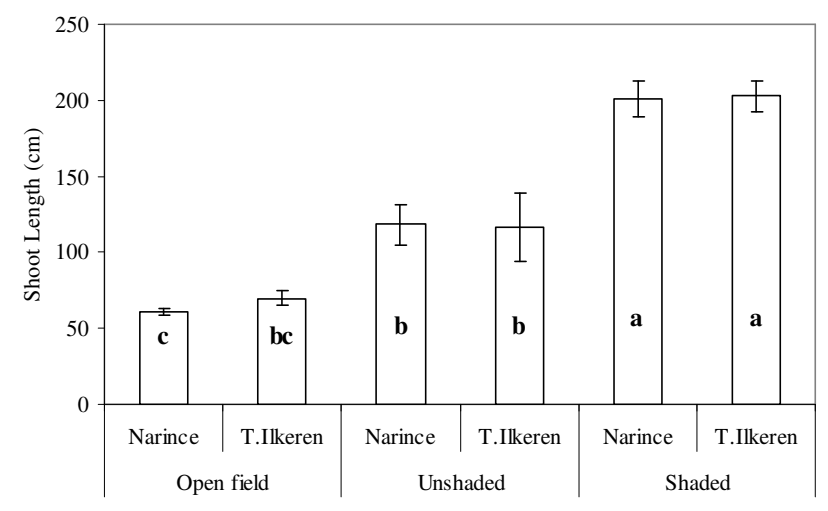

Fig. 4. Shoot lengths of grape cultivars grown in shaded and unshaded greenhouses and in the open field conditions in two different years; means with different letters in the same column were significantly different at $\mathrm{P}<0.05$

\section{Leafgrowth and development}

The total and mean leaf areas of grape cultivars grown under different conditions (shaded and unshaded greenhouses and open field conditions) with respect to years and cultivars are presented in Tab. 2. Growth conditions significantly affected the leaf areas of different varieties. Tab. 2 shows that the grape cultivar has a significant effect upon mean and total leaf area and there were significant effects of the year and nursery conditions on leaf area. The mean and total leaf areas of grapes which were grown under shaded greenhouse conditions were significantly higher than those grown under unshaded greenhouse and open field conditions in both years (Tab. 3). On the other hand, growth conditions $\mathrm{x}$ cultivar $\mathrm{x}$ year interaction had a significant effect on total leaf area but not on mean leaf area. Significant differences were observed in leaf areas of cultivars (Fig. 5). The average total leaf area of vines was calculated as $5229 \mathrm{~cm}^{2}$ in the first year and as $2869.3 \mathrm{~cm}^{2}$ in the second year. Similarly, mean leaf areas of the first and second years were respectively observed as 74.3 and $63.3 \mathrm{~cm}^{2}$ (Tab. 2). The highest total leaf area was at shaded 'Trakya Ilkeren' $\left(6154 \mathrm{~cm}^{2}\right)$ whereas the lowest at open field 'Narince' cultivar $\left(2643 \mathrm{~cm}^{2}\right)$. However, the highest mean leaf area was at shaded 'Narince' $\left(107.2 \mathrm{~cm}^{2}\right)$, whereas the least mean leaf area was at unshaded 'Trakya Ilkeren' (40.8 $\mathrm{cm}^{2}$ ) cultivar. Reducing light intensity led to the increased leaf area of cultivars. Bonan (2002) was impressed that leaves growing in sunny environments were smaller and more deeply lobed than leaves growing in shaded environments. Furthermore, the leaf area ratio was 2.7 times greater and leaf weight ratio was about $20 \%$ greater in shaded plants compared with sun plants. The reported acclimation to low light was not restricted to dry-weight allocation among shoot organs because the specific leaf area 
511

was increased to about $100 \%$ by the low-light environment. Increased shading resulted in increased leaf areas and wider leaves. Gutschick and Wiegel (1988) stated that deeper shade allowed plants to construct a greater leaf surface area for light interception at a certain biomass investment in foliage. Excess sun energy may have harmful effects on the photosynthetic devices, and plants arrange morphological, biochemical and physiological strategies to minimize these effects (Lichtenthaler and Burkart, 1999; Lichtenthaler et al., 2007). Leaf area plays a key role in determining crop productivity by controlling the interception of solar radiation (Monteith, 1977). In grapevines, the rate of photosynthesis production of fully expanded leaves depends on air temperature (Buttrose, 1969). In addition, there is a direct connection between intercepted solar radiation and plant leaf area to shoot development and accumulated assimilates in plant organs. For example, Cartechini and Palliotti (1995) reported that grapevines acclimate to modified light intensity and produce a given amount of carbohydrates. Shade-grown vines (30\% PPF) had lower total leaf area and soluble carbohydrates per plant and lower starch content in leaves compared to light adapted grapevines. Buttrose (1968) reported that cuttings of grapevines stem lengths and leaf area values grown in growth cabinets were in most cases greatest at $25{ }^{\circ} \mathrm{C}$ followed in turn by $30{ }^{\circ} \mathrm{C}$ and $20^{\circ} \mathrm{C}$ values. Miller $e t$ al. (1996) indicated a linear relationship between leaf area and shoot lengths of vines. In the research, a relationship was observed between leaf area and shoot length. Shoot length, total and mean leaf areas of the grafted vines grown under shaded greenhouse conditions were higher than that grown under other conditions. There was a highest correlation observed between shoot length, total and mean leaf area (Tab. 6). Total leaf area was correlated between trunk diameter $(\mathrm{r}=0.577, p<0.01)$, shoot diameter $(\mathrm{r}=0.646$, $p<0.01)$ and shoot length $(\mathrm{r}=0.819, p<0.01)$ per plant.

$$
\square \text { Total } \quad-\text { Mean }
$$

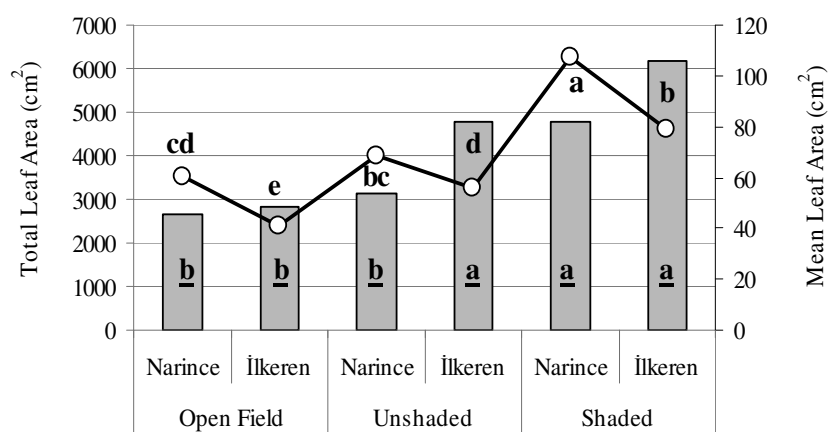

Fig. 5. Total and mean leaf areas of grape cultivars grown in shaded and unshaded greenhouses and in the open field conditions in two different years; means with different letters were significantly different at $\mathrm{P}<0.05$

\section{Plant carbohydrate contents}

The total soluble sugars, starch and total carbohydrate contents of different grafted vine cultivars under different growth conditions (shaded and unshaded greenhouses and open field) are presented in Tab. 4. Growth conditions had significant impacts on sugar, starch and carbohydrate contents of grafted vines (Tab. 5).
Data showing significant effects was obtained concerning interactions such as growth conditions $\mathrm{x}$ cultivar, cultivar $\mathrm{x}$ year and growth conditions $\mathrm{x}$ cultivars $\mathrm{x}$ year $(p<0.05)$. While significant differences were observed in sugar and starch contents of the years, effects of years on carbohydrate contents were not significant (Tab. 4). While the first year's sugar content was high and starch was low, the second year's sugar content was low and starch was high. So in both years, total carbohydrate content was not significant.

In the study, the total soluble sugars, starch and total carbohydrate content of the vines grown under unshaded greenhouse conditions were higher than that of the other conditions (Fig. 6). Effects of cultivars $\mathrm{x}$ conditions on starch and carbohydrate content were significant except for sugar only in the open field condition (Tab. 4). In spite of that, the mean sugar content of grafted vines grown under shaded greenhouse conditions $\left(14.6 \mathrm{mg} \mathrm{L}^{-1}\right)$ and unshaded greenhouse conditions $\left(14.3 \mathrm{mg} \mathrm{L}^{-1}\right)$ were found to be a bit higher than the ones grown under open field conditions (12.4 $\left.\mathrm{mg} \mathrm{L}^{-1}\right)$ (Tab. 5).

Carbohydrate contents of grapevines in this study were significantly affected by growth conditions. Starch and carbohydrate contents of plants grown under unshaded greenhouse conditions were higher than the plants grown under shaded greenhouse and open field conditions (Tab. 5, Fig. 6). Growth conditions $x$ year, cultivar $x$ year and growth conditions $\mathrm{x}$ cultivar $\mathrm{x}$ year interactions were found to be significant with regard to sugar, starch and carbohydrate content. Mean sugar content was $15.8 \mathrm{mg} \mathrm{L}^{-1}$ in the first year and $11.8 \mathrm{mg} \mathrm{L}^{-1}$ in the second year; starch content was 38.5 $\mathrm{mg} \mathrm{L}^{-1}$ in the first year and $43.4 \mathrm{mg} \mathrm{L}^{-1}$ in the second year; carbohydrate content was $54.3 \mathrm{mg} \mathrm{L}^{-1}$ in the first year and $55.2 \mathrm{mg} \mathrm{L}^{-1}$ in the second year (Tab. 4). In brief, the sugar, starch and carbohydrate content of plants grown under high light intensity $\left(1846.1 \mu \mathrm{molm}^{-2} \mathrm{~s}^{-1}\right)$ and low temperature $\left(18.8^{\circ} \mathrm{C}\right)$ conditions (open field) were lower than the ones grown under lower light but higher temperature conditions (662.2 $\mathrm{molm}^{-2} \mathrm{~s}^{-1}, 22.1{ }^{\circ} \mathrm{C}$ for shaded greenhouses and $1315.4 \mu \mathrm{molm}^{-2} \mathrm{~s}^{-1}, 24.9^{\circ} \mathrm{C}$ for unshaded greenhouses). However, the highest sugar, starch and carbohydrate content was obtained around $25^{\circ} \mathrm{C}$ and $30 \%$ lower light intensity (unshaded) in all the conditions (Fig. 6). Such a case seemed to be related to decreased photosynthesis efficiencies under high light but low temperature conditions. Among growth conditions, average relative humidity varied. The highest relative humidity $(66 \%)$ was observed under shaded greenhouse conditions and the lowest (45.4\%) under open field conditions (Tab. 1). Relative humidity of the first year was higher than that of the second year under all growth conditions. According to Jang et al. (2011) generally, 75-85\% relative humidity levels accelerate the photosynthesis rate. In grapevines, carbohydrates in roots and wood portions play important roles for vine longevity and quality. Indeed, carbohydrates are not only involved in the protection against frost (Keller, 2010), but they also take part in leaf area development, shoot growth and flower induction (Keller and Koblet, 1994; Murisier and Aerny, 1994; Yang and Hori, 1979). Carbohydrate accumulation correlated with photosynthesis efficiency in the plants. In addition, photosynthesis is highly dependent on temperature, light intensity and relative 
humidity (Gomes-Laranjo et al., 2006; Koorneef et al., 2002). It was reported that the optimal temperature range for photosynthesis was between $26-30^{\circ} \mathrm{C}$, with a decrease of about $50 \%$ when the temperature increases to $32-34^{\circ} \mathrm{C}$; the decrease being higher than $80 \%$ when temperatures reach $38{ }^{\circ} \mathrm{C}$ in chestnut (Gomes-Laranjo et al., 2006). Schultz and Matthews (1993) stated that in potted-grown White Riesling grapes dry-weight allocation of leaves of shaded plants was 9\% greater, whereas allocation to stem tissue was $10 \%$ less than in sun plants. Photosynthesis rates decrease at temperatures above the optimum levels (Spayd, 2000). In the case of temperatures up to $40{ }^{\circ} \mathrm{C}$, the photosynthesis of grapevine leaves are significantly reduced (Ferrini et al., 1995; Kriedemann, 1968; Yu et al., 2009; Zsofi et al., 2009). Greer and Weedon (2012) reported remarkable decreases in the photosynthesis of Semillon grape leaves at temperatures above $35{ }^{\circ} \mathrm{C}$. In part, these reductions in photosynthesis are related to stomatal limitation due to high temperature (Ferrini et al., 1995; Sepúlveda and Kliewer, 1986; Soar et al., 2009).

Most of the physiological processes of plants are related to carbohydrates. Carbohydrates are the most important products of photosynthesis and they are the most significant component of various physiological processes. In general, carbohydrates constitute about $50-80 \%$ of the total dry weight of most plants (Eris, 1990). Goldschmidth (1997)

Tab. 4. The sugar, starch and total carbohydrate content $\left(\mathrm{mg} \mathrm{L}^{-1}\right)$ of grafted vines grown under shaded and unshaded greenhouses and open field conditions

\begin{tabular}{|c|c|c|c|c|}
\hline $\begin{array}{l}\text { Growth } \\
\text { conditions }\end{array}$ & Cultivars & Sugar & Starch & Carbohydrate \\
\hline \multicolumn{5}{|c|}{ First Year } \\
\hline \multirow{2}{*}{ Open field } & 'Narince' & 14.0 & 30.7 & 44.7 \\
\hline & 'T.Ilkeren' & 13.8 & 34.2 & 47.9 \\
\hline \multirow{2}{*}{ Unshaded } & 'Narince' & 16.3 & 35.5 & 51.8 \\
\hline & 'T.Ilkeren' & 18.1 & 48.7 & 66.8 \\
\hline \multirow{2}{*}{ Shaded } & 'Narince' & 14.6 & 36.0 & 50.5 \\
\hline & ‘T.Ilkeren’ & 18.0 & 46.1 & 64.1 \\
\hline \multicolumn{5}{|c|}{ Second Year } \\
\hline \multirow{2}{*}{ Open field } & 'Narince' & 11.0 & 39.2 & 50.2 \\
\hline & 'T.Ilkeren' & 10.9 & 38.9 & 49.8 \\
\hline \multirow{2}{*}{ Unshaded } & 'Narince' & 13.1 & 57.5 & 70.6 \\
\hline & 'T.Ilkeren' & 10.9 & 44.3 & 55.2 \\
\hline \multirow{2}{*}{ Shaded } & 'Narince' & 13.6 & 41.5 & 55.1 \\
\hline & 'T.Ilkeren' & 11.2 & 39.1 & 50.3 \\
\hline \multicolumn{2}{|l|}{ Pooled SEM ${ }^{*}$} & 0.089 & 0.235 & 0.236 \\
\hline \multicolumn{2}{|l|}{ Conditions } & $*$ & * & * \\
\hline \multicolumn{2}{|l|}{ Cultivars } & N.S & $*$ & $*$ \\
\hline \multicolumn{2}{|l|}{ Year } & $*$ & * & N.S \\
\hline \multicolumn{2}{|c|}{ Conditions x Cultivars } & N.S & $*$ & * \\
\hline \multicolumn{2}{|c|}{ Conditions x Year } & * & $*$ & * \\
\hline \multicolumn{2}{|c|}{ Cultivar x Year } & $*$ & * & * \\
\hline \multicolumn{2}{|c|}{ Conditions $\mathrm{x}$ Cultivars $\mathrm{x}$ Year } & * & $*$ & $*$ \\
\hline
\end{tabular}

Tab. 5. Mean sugar, starch and carbohydrate contents $\left(\mathrm{mg} \mathrm{L}^{-1}\right)$ of grafted vines grown under shaded and unshaded greenhouses and open field conditions

\begin{tabular}{llcc}
\hline Growth conditions & Sugar & Starch & Carbohydrate \\
\hline Open field & $12.4 \mathrm{~b}$ & $35.8 \mathrm{c}$ & $48.1 \mathrm{c}$ \\
Unshaded & $14.3 \mathrm{a}$ & $46.5 \mathrm{a}$ & $61.1 \mathrm{a}$ \\
Shaded & $14.6 \mathrm{a}$ & $40.7 \mathrm{~b}$ & $55.0 \mathrm{~b}$ \\
\hline Means with different letters & in the same column were significantly different
\end{tabular}

Means with different letters in the same column were significantly different $\left({ }^{*} p<0.05\right)$. indicated the role of carbohydrates in various physiological processes of plants as the source of energy. Monteith (1977) reported linear relationships between dry matter accumulation and total PAR (Photosynthetic Active Radiation) up to a certain point. However, since high light intensities may damage plant chlorophylls, photosynthetic efficiencies of plants may decrease because of photoinhibition. Bertamini and Nedunchezhian (2004) reported net photosynthesis under low and high light intensities respectively as 42 and $76 \%$ lower than the normal light conditions. Thus, photosynthesis rates increase at optimum temperature levels. Since the average temperatures in shaded and unshaded greenhouses were within the optimum range of temperature $\left(25-30{ }^{\circ} \mathrm{C}\right)$ for photosynthesis, the plants had higher carbohydrate contents under shaded and unshaded greenhouse conditions than those under open field conditions. Higher total and mean leaf areas of the plants under shaded and unshaded greenhouse conditions also resulted in higher carbohydrate contents for those plants than the ones grown under open field conditions (high light, low average temperature). Accordingly, there was also a significant correlation between total leaf area and sugar content (Tab. $6 ; \mathrm{r}=0.695, p<0.01$ ).
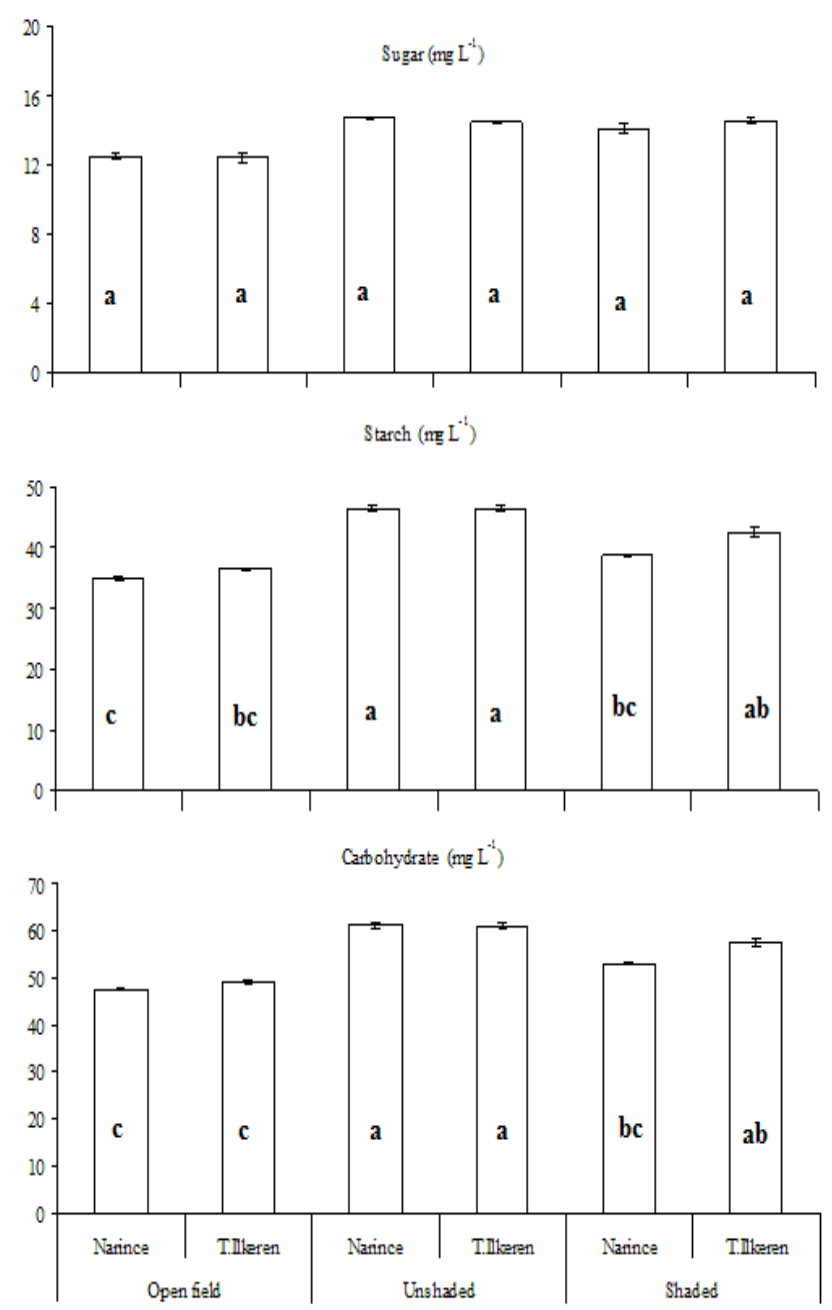

Fig. 6. Sugar, starch and total carbohydrate content of grape cultivars grown in shaded and unshaded greenhouses and in the open field conditions in two different years; means with different letters were significantly different at $\mathrm{P}<0.05$ 
Tab. 6. Correlations amongst the plant growth parameters and carbohydrates

\begin{tabular}{|c|c|c|c|c|c|c|c|}
\hline Parameters & Sugar & Starch & Carbohydrate & $\begin{array}{c}\text { Total Leaf } \\
\text { Area }\end{array}$ & $\begin{array}{c}\text { Trunk } \\
\text { Diameter }\end{array}$ & $\begin{array}{c}\text { Mean Leaf } \\
\text { Area }\end{array}$ & $\begin{array}{c}\text { Shoot } \\
\text { Diameter }\end{array}$ \\
\hline Starch & 0.134 & & & & & & \\
\hline Carbohydrate & $0.444^{\prime \prime}$ & $0.948^{*}$ & & & & & \\
\hline Total Leaf Area & $0.695^{\prime \prime}$ & 0.068 & $0.286^{\circ}$ & & & & \\
\hline Trunk Diameter & $0.544^{\prime \prime}$ & $-0.403^{\prime \prime}$ & -0.189 & $0.577^{\prime \prime}$ & & & \\
\hline Mean Leaf Area & $0.356^{\circ}$ & -0.032 & 0.086 & $0.555^{*}$ & $0.339^{\circ}$ & & \\
\hline Shoot Diameter & $0.742^{* \prime}$ & -0.232 & 0.030 & $0.646^{*}$ & $0.706^{* \prime}$ & $0.319^{*}$ & \\
\hline Shoot Length & $0.447^{\prime \prime}$ & 0.129 & 0.261 & $0.819^{* *}$ & $0.354^{*}$ & $0.754^{* *}$ & $0.395^{\prime \prime}$ \\
\hline
\end{tabular}

${ }^{* *}$ Correlation is significant at the $p<0.01$ level (2-tailed).

${ }^{*}$ Correlation is significant at the $p<0.05$ level (2-tailed).

\section{Conclusions}

According to the results of this study, vines' growth and quality characteristics were affected by different growth conditions. The vines grown under unshaded and shaded conditions exhibited higher performances than the ones grown under open field conditions. Shoot lengths and leaf areas were especially affected by decreasing light intensities and increasing temperatures. Additionally, the carbohydrate content of vines was affected by growth conditions. Higher carbohydrate levels were observed under increasing temperature and decreasing light intensity conditions as opposed to higher light intensity and lower temperature conditions. However, all three growth conditions produced top quality vines. Providing optimum temperature or the establishment of nurseries obtaining these temperature regions is gaining importance in the area of quality grapevine production. To reduce the negative impact of high light intensity on plants, canopy shading throughout the growth cycle should be provided. In this study, better growth and quality results were obtained under high temperatures $\left(25^{\circ} \mathrm{C}\right)$ and low light intensity conditions $\left(1300 \mu \mathrm{mol} \mathrm{m}^{-2} \mathrm{~s}^{-1}\right)$.

\section{References}

Agaoglu SY, Ayfer M, Fidan F, Köksal I, Çelik M, Abak K, Celik H, Kaynak L, Gülsen Y (1995). General Horticulture. Ankara University Agricultural Faculty Press, Volume No: 1009, Ankara, Turkey, 283 p.

Anonymous (1995). Turkish Standard of Grape Vine (TS 3981). Necatibey Street 112. Ministries Ankara (in Turkish).

Arnold DH, Mauseth JD (1999). Effects of environmental factors on development of wood. Americ J of Botany 86(3):367-371.

Baldocchi, DD, Amthor JS (2001). Canopy Photosynthesis: History, measurements and models, p. 9-31. In: J. Roy, B. Saugier and H. Mooney (Eds.). Terrestrial Global Productivity: Past, Present and Future. Academic Press, San Diego.

Bates TR, Dunst RM, Joy P (2002). Seasonal dry matter, starch, and nutrient distribution in 'Concord' grapevine roots. HortScience 37(2):313-316.

Bertamini M, Nedunchezhian N (2004). Phoptosynthetic responses for Vitis vinifera plants grown at different photon flux densities under field conditions. Biologia Plantarum (48):149-152.
Bindi M, Miglietta F, Gozzini B, Orlandini S, Seghi L (1997). A simple model for simulation of growth and development in grapevine (Vitis vinifera L.) I. Model description. Vitis 36(2):67-71.

Bonan GB (2002). Ecological climatology: concepts and applications. Cambridge University Press, 678 p.

Buttrose MS (1968). Some Effects of Light Intensity and Temperature on Dry Weight and Shoot Growth of GrapeVine. Ann Bot 32(4):753-765.

Buttrose MS (1969). Fruitfulness in grapevines: Effects of light intensity and temperature. Botanical gazette 130(3):166-173.

Cangi R, Kelen M, Doğan A (1999). The posibility of grapevine production in cool climate conditions. Turkey $3^{\text {rd }}$ National Horticulture Congress. 14-17 September 1999, Ankara, Turkey. p. 430-435 (in Turkish).

Candolfi-Vasconcelos MC, Koblet W (1990). Yield, fruit quality, bud fertility and starch reserves of the wood as a function of leaf removal in Vitis vinifera - Evidence of compensation and stress recovering. Vitis (29):199-221.

Cartechini A, Palliotti A (1995). Effect of shading on vine morphology and productivity and leaf gas exchange characteristics in grapevines in the field. Am J Enol Vitic 46(2):227-234.

Çelik S, Delice A, Arın L (1992). The grafted grapevine production in the nursery condition. Tr J Agric Forestry 16:507-518.

Eris A (1990). Physiology of Horticulture. Uludag University Lecture Notes No:11, Bursa, Turkey (in Turkish).

Elsner EA, Jubb GL (1988). Leaf Area Estimation of Concord Grape Leaves from Simple Linear Measurements. Am J Enol Vitic 39(1):95-97.

Ferrini F, Mattii GB, Nicese FP (1995). Effect of temperature on key physiological responses of grapevine leaf. Am J Enol Vitic 46(3):375-379.

Field SK, Smith JP, Holzapfel BP, Hardie WJ, Emery RN (2009). Grapevine response to soil temperature: xylem cytokinins and carbohydrate reserve mobilization from budbreak to anthesis. Am J Enol Vitic 60(2):164-172.

Fluhr R, Moses P, Morelli G, Coruzzi G, Chua NH (1986). Expression dynamics of the pea $\mathrm{rbcS}$ multigene family and organ distribution of the transcripts. EMBO J 5(9):20632071. 
Greer DH, Weedon MM (2012). Modelling photosynthetic responses to temperature of grapevine (Vitis vinifera $\mathrm{cv}$. Semillon) leaves on vines grown in a hot climate. Plant, Cell and Environment 35(6):1050-1064.

Goldschmidth EE (1997). Carbohydrate supply as a limiting factor for citrus fruit growth and productivity. HortScience 32(3): 550-551.

Gomes-Laranjo J, Peixoto F, Wong Fong Sang HW, TorresPereira J (2006). Study of the temperature effect in three chestnut (Castanea sativa Mill.) cultivars' behavior. J of Plant Phys 163(9): 945-955.

Gutschick VP, Wiegel FW (1988). Optimizing the canopy photosynthetic rate by patterns of investment in specific leaf mass. The American Naturalist 132(1):67-86.

Hale CR, Weaver RJ (1962). The efect of developmental stage on direction of translocation of photosynthate in Vitis vinifera. Hilgardia 33(3):89-131.

Jang Y, Goto E, Ishigami Y, Mun B, Chun C (2011). Effects of light intensity and relative humidity on photosynthesis, growth and graft-take of grafted cucumber seedlings during healing and acclimatization. Horticulture, Environment, and Biotechnology 52(4): 331-338.

Karakır MN, Uzun HI, İlter E (1988). The research of Yuvarlak Çekirdeksiz grape variety grafted on $5 \mathrm{BB}$ and $99 \mathrm{R}$ rootstocks; graft success, rooting and anatomical investigation of graft union. Turkey $3^{\text {rd }}$ Viticultural Symposium, pp. 88-92, Bursa, Turkey (in Turkish).

Keller M (2010). The Science of Grapevines. Anatomy and Physiology. Academic Press London, 400 p.

Keller M, Koblet W (1994). Is carbon starvation rather than excessive nitrogen supply the cause of inflorescence necrosis in Vitis viniferous? Vitis 33:81-86.

Kısmalı I (1984). The research of some of the table grape varieties on winter bud fertility. $2^{\text {rd }}$ Turkish National Viticulture and Enology Symposium, 14-17 November 1983, pp. 35-48, Manisa, Turkey (in Turkish).

Koblet W (1984). Influence of light and temperature on vine performance in cool climates and applications to vineyard management, p. 139-157. In: Heatherbell DA, Lombard, PB, Bodyfelt FW, Price SF (Eds.). Proc Int Symp on Cool Climate. Vitic Enol Oregon State University, Oregon.

Koornneef M, Bentsink L, Hilhorst H (2002). Seed dormancy and germination. Current Opinion Plant Biol 5: 33-36.

Kriedemann PE (1968). Photosynthesis in vine leaves as a function of light intensity, temperature, and leaf age. Vitis $7: 213-220$.

Lichtenthaler H, Burkart S (1999). Photosynthesis and high light stress. Bulgarian J Plant Physiology 25(3-4):3-16.

Lichtenthaler H, Marek A, Kalina J, Urban O (2007). Differences in pigment composition, photosynthetic rates and chlorophyll fluorescence images of sun and shade leaves of four tree species. Plant Physiology and Biochemistry 45(8):577-588.

Luo HB, Ma L, Xi HF, Duan W, Li SH, Loescher W, Wang JF,
Wang LJ (2011). Photosynthetic responses to heat treatments at different temperatures and following recovery in grapevine (Vitis amurensis L.) leaves. PLoS One 6(8):e23033.

Miller DP, Howell GS, Flore AJ (1996). Effect of Shoot Number on Potted Grapevines: I. Canopy Development and Morphology. Am J Vitic 47(3):247-250.

Matloobi, M (2012). Light harvesting and photosynthesis by the canopy. Advances in photosynthesis - fundamental aspects. InTech: Janeza Trdine 9(51000):235-256.

Monteith JL (1977). Climate and the efficiency of crop production in Britain. Physiological Translocations of the Royal Society of London 281:277-294.

Mullins MG, Bouquet A, Williams LE (1992). Biology of grapevine. Cambridge Univ Pres, Cambridge, UK, P. 252.

Murisier F, Aerny J (1994). Influence du niveau de rendement de la vigne sur les réserves de la plante et sur la chlorose. Rôle du porte-greffe. Rev Suisse Vitic Arboric. Hortic 26(5):281-287.

Neri D, Battistelli R, Albertini G (2003). Effects of low-light intensity and temperature on photosynthesis and transpiration of Vigna sinensis L. J Fruit Ornamental Plant Res 11:17-24.

Oztürk A, Serdar U (2011). Effects of different nursery conditions on the plant development and some leaf characteristics in Chestnuts (Castanea sativa Mill.). Aust J Crop Sci 5(10):1218-1223.

Richards M (1976). Propagation of grapes by grafting. Plant Propagator 22(1):9-10.

Sepúlveda G, Kliewer WM (1986). Effect of high temperature on grapevines (Vitis vinifera L.). II. Distribution of soluble sugars. American Journal of Enology and Viticulture 37(1):20-25.

Schultz H (2000). Climate change and viticulture: A European perspective on climatology, carbon dioxide and UV-B effects. Aust J Grape and Wine Res 6(1):2-12.

Schultz HR, Matthews MA (1993). Xylem development and hydraulic conductance in sun and shade shoots of grapevine (Vitis vinifera L.): evidence that low light uncouples water transport capacity from leaf area. Planta 190(3):393-406.

Scott TA, Melvin EH (1953). Determination of Dextran with Anthrone. Anal Chem 25(11):1656-1661.

Sivritepe N, Türkben C (2001). The Effects of Different Rootstocks on Grafting Success and Ratio of Grafted Vine in Müşküle Grapevine Cultivar. J Uludag Uni Agr Fac 15:47-58 (in Turkish).

Skelton S (2007). Viticulture - An introduction to commercial grape growing for wine production. Lulu Com London p. 146.

Spayd S (2000). The casual cellar rat explores the importance of leaves. Grape Research News. Washington State University Press 11(2):1-11.

Soar CJ, Collins MJ, Sadras VO (2009). Irrigated Shiraz vines upregulate gas exchange and maintain berry growth under short spells of high maximum temperature in the field. Funct Plant Biol 36(9):801-814. 
515

Troncoso A, Atte CM, Cantos M (1999). Evaluation of salt tolerance of in vitro-grown grapevine rootstock varieties. Vitis 38:55-60.

Uzun S, Demir Y (1996). The effect of temperature on plant growth, development and productivity (II. Growth). J Agr Fac OMU 11(3):201-212 (in Turkish).

Vršič S, Valdhuber J, Pulko B (2004). Compatibility of the rootstock Börner with various scion varieties. Vitis 43:155156.

Wang WH, Chen J, Liu TW, Han AD, Simon M, Dong XJ, He HX, Zheng HL (2014). Regulation of the calcium-sensing receptor in both stomatal movement and photosynthetic electron transport is crucial for water use efficiency and drought tolerance in Arabidopsis. J Experimental Botany 65(1):223-234.

Yang YS, Hori Y (1979). Studies on retranslocation of accumulated assimilates in Delaware grapevines. I. Retranslocation of ${ }^{14} \mathrm{C}$ assimilates in the following spring after ${ }^{14} \mathrm{C}$ feeding in summer and autumn. Tohoku J Agric Res 30:43-56.
Yllma P (1996). The effect of different grafting time and nursery systems on grafted grapevine production by grafted cuttings directly planted in the nursery. Ondokuz Mayis University, MSD Thesis. Applied and Natural Sciences Institute. Samsun, Turkey, p. 126 (in Turkish).

Yu DJ, Kim SJ, Lee HJ (2009). Stomatal and non-stomatal limitations to photosynthesis in field-grown grapevine cultivars. Biol Plant 53(1):133-137.

Zsófi Z, Gál L, Szilágy Z, Szücs E, Marschall M, Nagy Z, Bálo B (2009). Use of stomatal conductance and pre-dawn water potential to classify terroir for the grape variety Kékfrankos. Aust J Grape Wine Research 15(1):36-47. 